\title{
Numerical and Experimental Investigation on Physical Properties of Some Stones Existing in Several Regions of Turkey
}

\author{
Y. Bicer ${ }^{1}$, A. Devecioglu' ${ }^{2}$, D. Tunc ${ }^{1}$ \\ ${ }^{1}$ Department of Mechanical Engineering, Firat University, Elazig, Turkey \\ ${ }^{2}$ Department of Mechanical Engineering, Dicle Universitry, Diyabakir, Turkey \\ Email: ybicer@firat.edu.tr
}

Received November 2013

\begin{abstract}
Some of natural stones, which have various physical properties, are being used as building materials all over the world for ages. Although, it is sometimes by the reason of necessity, mostly the stone buildings have been preferred, because it is accepted as an indication of prosperity. In fact, the heat and mechanical features of these stones in relation to the seasonal comfort conditions have not been searched yet. In present study, some of physical properties of some stones existing in Eastern Turkey are held under microscope. A numerical analysis has been performed by using ANSYS software, which uses finite element methodology. By numerical method, it is aimed to show the transient heat transfer from the stones when they are used as a building material in a selected region in Turkey. Only winter case has been handled to show the usability of each stone.
\end{abstract}

\section{Keywords}

Building Materials, Stones, Thermal Characteristics, ANSYS

\section{Introduction}

Rock structures (stones) have existed for as long as history can recall. It is the longest lasting building material available, and is usually readily available. There are many types of rock throughout the world, all with differing attributes that make them better or worse for particular uses. Rock is a very dense material so it gives a lot of protection too; its main drawback as a material is its weight and awkwardness. Its energy density is also considered a big drawback, as stone is hard to keep warm without using large amounts of heating resources. Drystone walls have been built for as long as humans have put one stone on top of another. Eventually, different forms of mortar were used to hold the stones together, cement being the most commonplace now [1].

The Anatolia (Asian part of Turkey) hosts various kinds of natural stones which have been used in building as construction material by several civilizations from long in the past until more recently. Some of the buildings formed by those stones are big and significant buildings and their artistic, cultural and aesthetical features are quite attention-grabbing. The stones used in most of these buildings have been searched from the view point of civil engineers, or geologists. Some of them are listed following.

How to cite this paper: Bicer, Y., Devecioglu, A. and Tunc, D. (2014) Numerical and Experimental Investigation on Physical Properties of Some Stones Existing in Several Regions of Turkey. Journal of Applied Mathematics and Physics, 2, 316-322. 
Freeze-thaw test was conducted by Bayram [2] for determining the deteriorations of stones due to freeze-thaw cycling. Freeze-thaw tests were applied on nine limestone samples selected from different cold regions of Turkey. Ozcelik [3] searched suitable and unsuitable rocks from the region Cubuk (near to the capital city Ankara) for being facing and building stone, according to the TSE standards [3]. The quality and material properties of Denizli travertine as a natural building stone was investigated by Celik et al. [4]. Physical, mechanical, micro-structural and macro-structural properties of the travertine samples were evaluated within the scope of stone quality assessment [4].

Bicer et al. had searched the usage area of some stones from different regions of Turkey such as Mardin [5], Firat basin [6] and Cukurova [7]. They performed some tests to find out the availability of the stones in the construction. Korkanc [8] determined the engineering properties and deterioration of the stones widely used in the different historical buildings in the Nigde region that forms the southern boundary of Cappadocia.

Zedef et al. [9] investigated the chemical and physical properties of the volcanic rocks used as building stones in historical places and monuments. Yavuz [10] worked on the Alacati (in Izmir: western Turkey) tuff which has been used extensively as a source of building stone for outdoor and indoor decorations since the historical times in and around the tourist town of Alacati.

In present study, some physical properties of four kinds of stones existing in Eastern Turkey are held under microscope in detail. Some previously done measurements such as heat conductivity, heat capacity, water absorption, respiration and mechanical strength are used to conduct a numerical analysis. By this numerical method, which is carried out by use of Finite Element methodology, it is aimed to show the transient heat transfer from the stones when they are used as a building material in a selected region in Turkey.

\section{Properties of Natural Stones}

Natural stones from Karakocan, Karacadag, Yesilyurt and Nemrut are generally used as building materials for construction and decoration. Determining the mechanical and thermal properties of stones is important subject because the economic life in the source of those stones is quite bad. The cost of the stones is satisfactory, comparatively to the well-known concretes.

The origin source of these stones is Eastern Turkey. In Eastern Turkey especially the buildings in the villages, in which people afford to build their houses by themselves, those stones are preferred. In Figure 1, Turkey map is given to show the sources of the stones. The Karacadag stone is found in Diyarbakir, Karakocan stone in Elazig, Yesilyurt stone in Malatya, and Nemrut stone in Adiyaman.

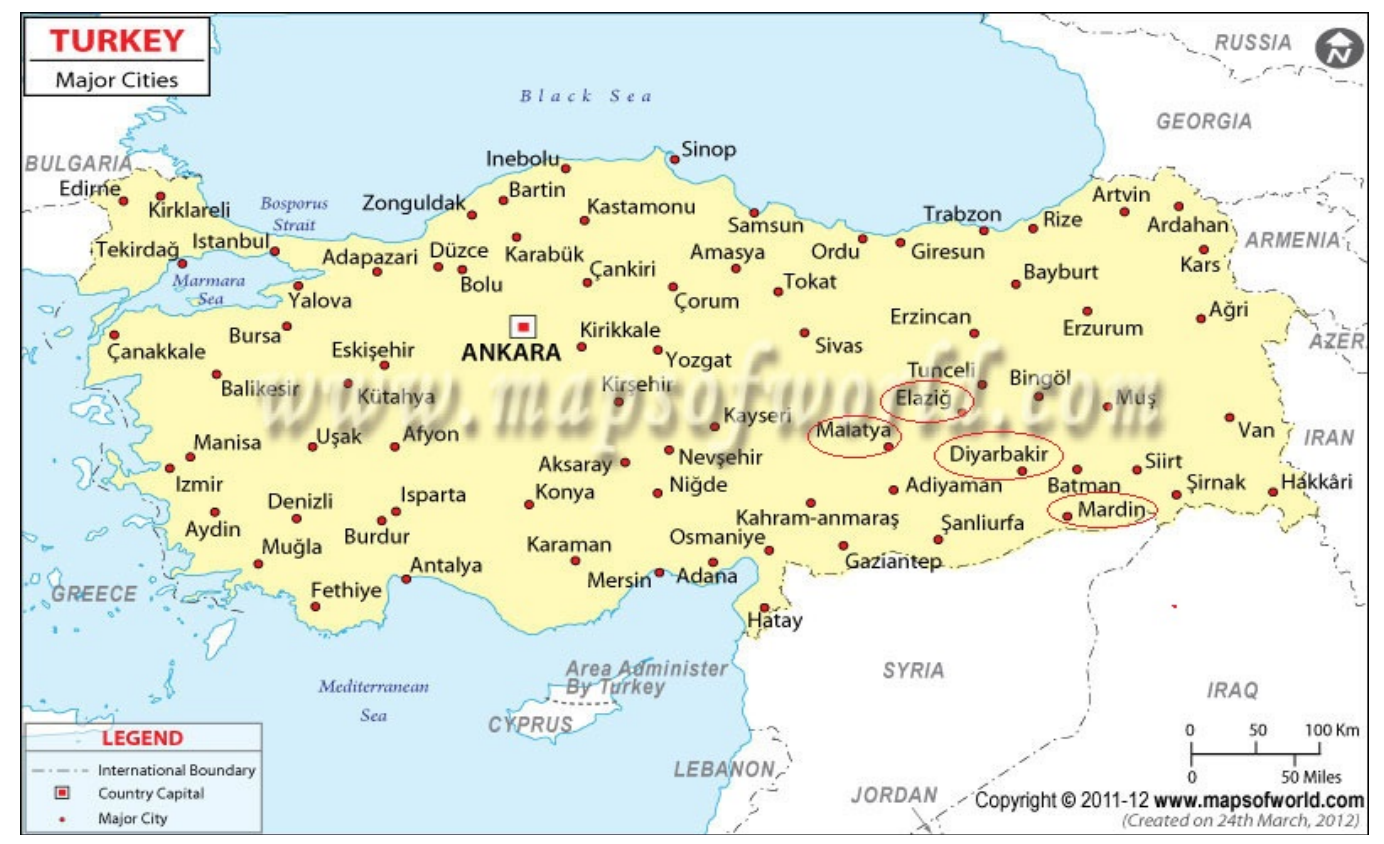

Figure 1. Sources of the stones. 
Karacadag stone is a magmatic extrusive volcanic stone, which is in the basalt group and black in color. It can be found in Diyarbakir and around. It is a hard stone (6-7 mohs), and not easy to be shaped. It was used in the construction of old rampart, and still being used in the villages and suburbs.

Yesilyurt stone is usually found in Malatya, it is a sandstone, and can be classified in the sedimentary rock group. It can be hardened with the fire. Hence it is commonly used in the construction of stone ovens.

Karakocan stone is the organic volcanic stone. The degree of the hardness of this stone is nearly 3 - 4 mohs. It can be easily shaped. It is especially used in the masonry buildings. It can absorb the water even after heated in the oven. If it can be protected from the external chemical effects, its usage area can be enlarged. It can be drilled, nailed and sculpted. These benefits make the stone attractive for the users.

Nemrut stone is the whitish limestone. It can be found at Nemrut Mountain. It can be easily shaped, drilled, cut, and nailed. It is inexpensive and so preferred in many buildings. Photos of each stone are presented in Figure 2.

The chemical analysis of each stone is given in Table 1. As seen clearly, the highest amount of element in the stone is $\mathrm{SiO}_{2}$, regardless what the stone is. But the highest $\mathrm{SiO}_{2}$ amount is found in Yesilyurt stone.

The mechanical properties, such as compressive strength, tension strength, absorption of the water and the abrasion is listed in Table 2. Karacadag stone has a very high compressive strength and tension strength comparatively to the other stones.

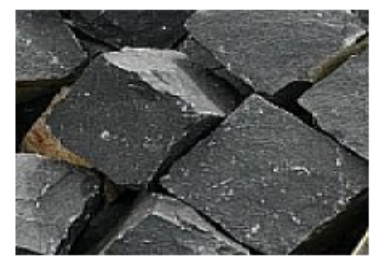

a) Karacadag

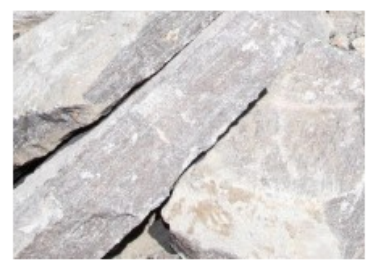

c) Yesilyurt

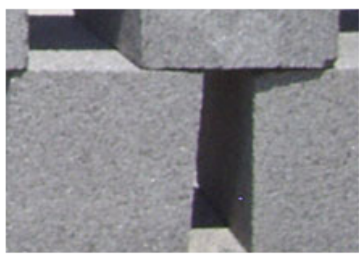

b) Karakocan

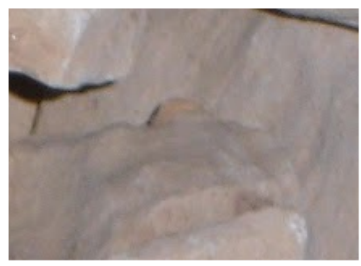

d) Nemrut

Figure 2. Photos of the stones.

Table 1. Chemical analysis of the stones (\%) [6].

\begin{tabular}{cccccccc}
\hline & $\mathbf{S i O}_{2}$ & $\mathrm{Al}_{2} \mathbf{O}_{3}$ & $\mathbf{F e}_{2} \mathbf{O}_{3}$ & $\mathbf{C a O}$ & $\mathbf{M g O}$ & Loss & Unknown \\
\hline Karacadag & 47.24 & 15.30 & 4.70 & 13.04 & 3.74 & 13.58 & 2.40 \\
Karakocan & 69.46 & 12.77 & 2.1 & 6.10 & 1.33 & 5.66 & 2.58 \\
Nemrut & 47.20 & 19.15 & 15.30 & 11.17 & 5.35 & - & 1.83 \\
Yesilyurt & 71.42 & 13.5 & 6.0 & - & - & 5.13 & 2.46 \\
\hline
\end{tabular}

Table 2. Mechanical properties of the stones [6].

\begin{tabular}{ccccc}
\hline & Compressive strength $\left(\mathbf{N} \cdot \mathbf{m m}^{-\mathbf{2}}\right)$ & Tension strength $\left(\mathbf{N} \cdot \mathbf{m m}^{-\mathbf{2}}\right)$ & Absorption of water $(\%)$ & Abrasion $(\%)$ \\
\hline Karacadag & 110 & 9.1 & 0.31 & 1.8 \\
Karakocan & 8.2 & 0.9 & 17.5 & 4.9 \\
Nemrut & 10.2 & 1 & 17 & 5.1 \\
Yesilyurt & 11.1 & 1.15 & 8.6 & 13.1 \\
\hline
\end{tabular}


The thermo physical properties of the stones which have been found by some tests buy the co-author (Bicer, Y.) of this paper is exhibited in Table 3. Table 3 also includes the properties of commonly used stones for comparison. As seen from the tables, Nemrut stone has the highest heat diffusion, Karacadag has the highest density and thermal conductivity. Furthermore, the specific heat is nearly close for all stones.

\section{Numerical Analysis}

In this section, the stones of which thermo physical and mechanical properties are mentioned in previous section are analyzed. The transient heat transfer analysis is performed by using ANSYS Thermal software. The solution domain with boundary layers is illustrated in Figure 3.

The winter weather condition in a certain place (Elazig) is assumed for the analysis. The outdoor temperature is considered to be $-10^{\circ} \mathrm{C}$ while the indoor temperature is kept $22^{\circ} \mathrm{C}$. The heat transfer coefficients respectively for outdoor and indoor air are 25 and $10 \mathrm{Wm}^{-2} \cdot \mathrm{K}^{-1}$. The thermal properties of the cement used in the stones connection, such as density, specific heat and thermal conductivity is ignored and the properties of the stones are assumed in the analysis.

The transient heat transfer analysis is carried out in this analysis. It is desired to show how the stones react when they are subjected to a cold weather, i.e. $-10^{\circ} \mathrm{C}$. In general, the steady state conditions are handled in such problems. However, we would like to see the difference between the stones' behavior, especially when a sudden temperature decrease is occurred. The first 12 hours are held under microscope in this analysis.

\section{Results}

The temperature results are shown with contour plots in Figure 4. As seen from the plots, general distribution is nearly same for all stones. When Figure 5 is considered, the differences in values can be seen clearly. The lowest temperature at the last time step, $-12 \mathrm{hr}$ - is found in the case of Karacadag stone. Also it is seen from the figure that, the other three stones have no significant difference. Figure 6 shows the temperature versus time

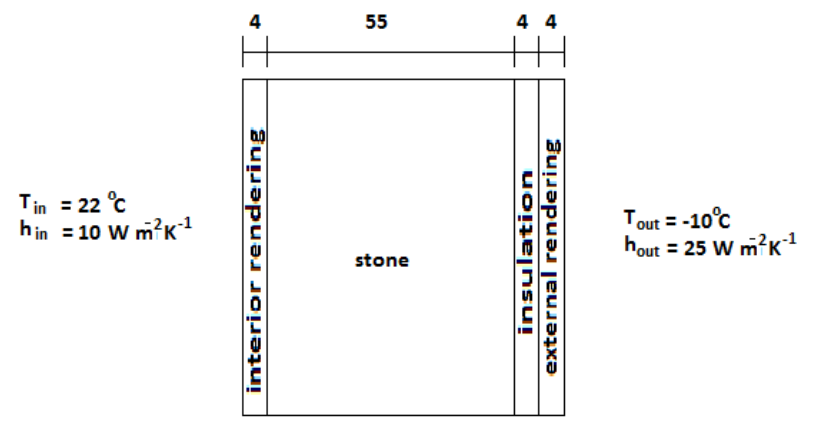

Figure 3. Solution domain and the boundary layer.

Table 3. Thermo physical properties of the stones.

\begin{tabular}{ccccc}
\hline & $\begin{array}{c}\text { Thermal conductivity } \\
\mathrm{k}\left(\mathrm{W} \cdot \mathrm{m}^{-1} \cdot \mathrm{K}^{-1}\right)\end{array}$ & $\begin{array}{c}\text { Specific heat } \\
\mathrm{Cp}\left(\mathrm{J} \cdot \mathrm{kg}^{-1} \cdot \mathrm{K}^{-1}\right)\end{array}$ & $\begin{array}{c}\text { Heat diffusion } \\
\alpha \times 10^{-7}\left(\mathrm{~m}^{2} \cdot \mathrm{s}^{-1}\right)\end{array}$ & $\begin{array}{c}\text { Density, } \\
\rho\left(\mathrm{kg} \cdot \mathrm{m}^{-3}\right)\end{array}$ \\
\hline Karacadag & 1.630 & 1128 & 4.988 & 2900 \\
Karakocan & 0.440 & 1027 & 3.360 & 1280 \\
Nemrut & 0.800 & 943 & 6.100 & 1400 \\
Yesilyurt & 1.18 & 1088 & 5.727 & 1900 \\
Concrete [11] & 0.814 & 879 & 4.9 & 1906 \\
Granite [11] & $1.73-3.98$ & 816 & $8-18.3$ & 2643 \\
Lime stone [11] & 1.26 & 908 & 5.68 & 2483 \\
Sand stone [11] & $1.63-2.08$ & 712 & $10.6-12.7$ & $2163-2307$ \\
Marble [11] & 2.77 & 808 & 3.94 & $2499-2707$ \\
Brick [11] & 0.692 & 837 & 5.16 & 1602 \\
\hline
\end{tabular}




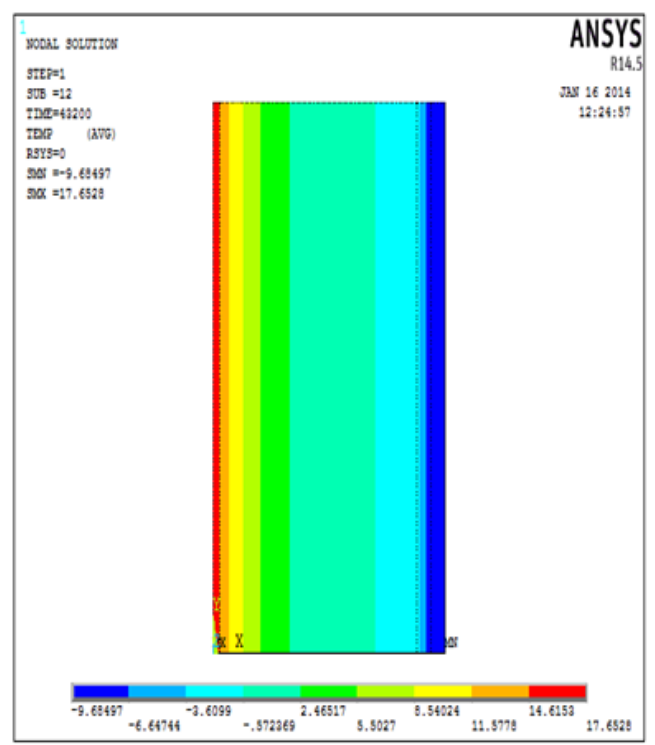

(a)

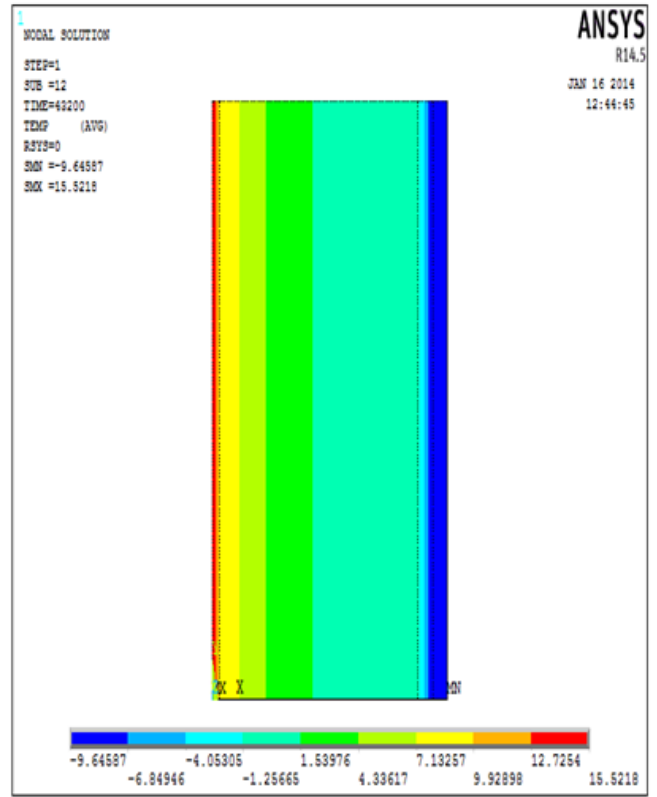

(c)

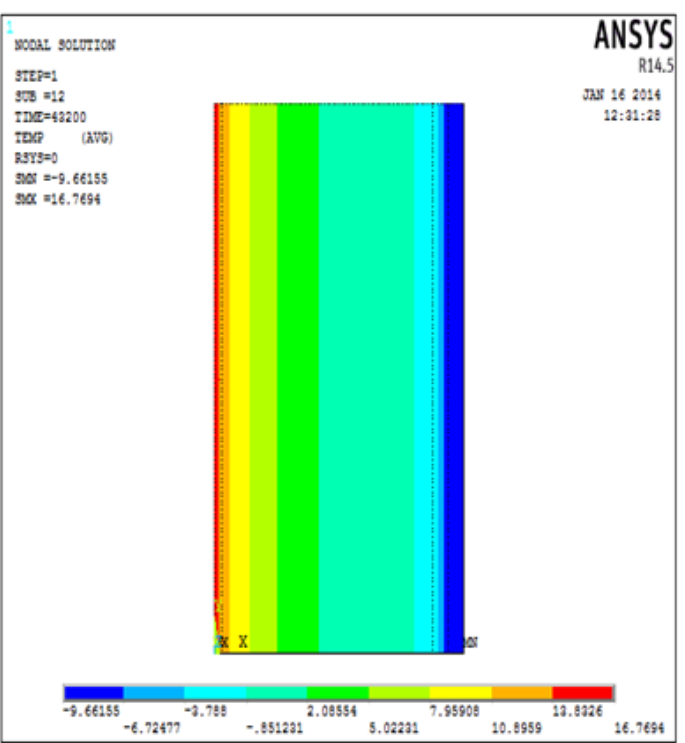

(b)

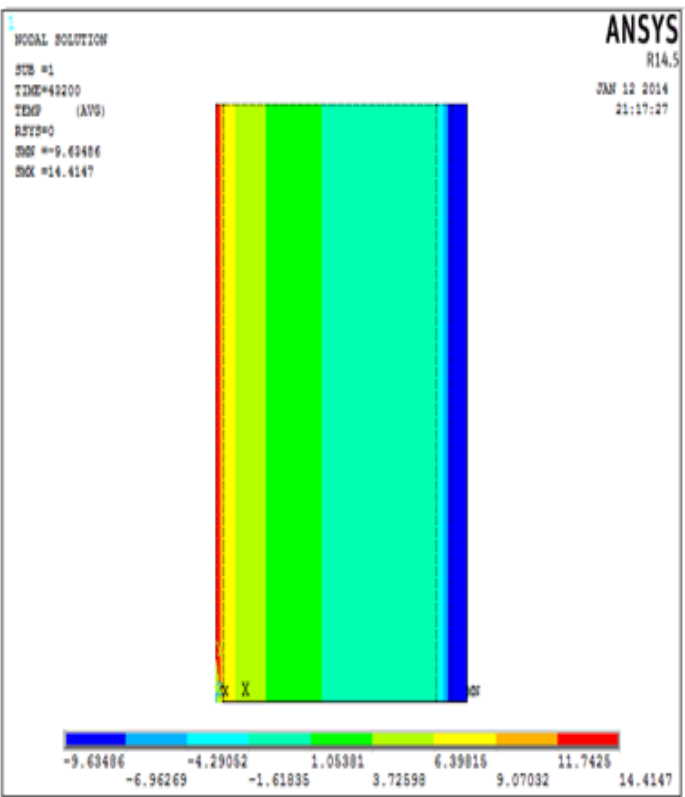

(d)

Figure 4. Contour plot temperature of all stones at the last time step (12 hr). (a) Karakocan; (b) Nemrut; (c) Yesilyurt; (d) Karacadag.

graphs for all stones at a selected node (center of the wall, $x=59 \mathrm{~cm}$ ). The temperature differences can easily be seen in this graph. Nemrut stone has the highest temperature at the selected node during the considered period of time. Then Yesilyurt, Karakocan and Karacadag stones come in order. It is also observed from the graph that, there is no quite difference between the temperatures in the first two hours. The temperatures are changing after $t=2 \mathrm{hr}$.

\section{Conclusion}

This paper shows the heat transfer behavior of some natural stones in the first 12 hours. It is important to see the reaction of the stones to the temperature changings especially if they are used as the building material. Hence the transient heat transfer analysis is performed to see the temperature characteristics of the stones during a limited 


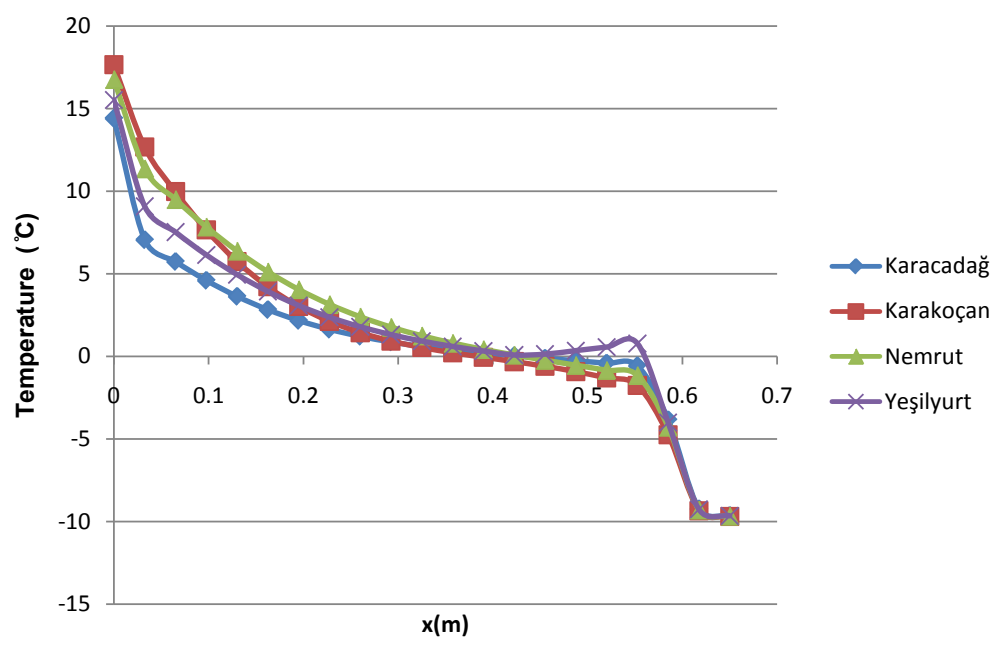

Figure 5. Temperature distribution along the axial distance of the wall at the last time step (12 hr).

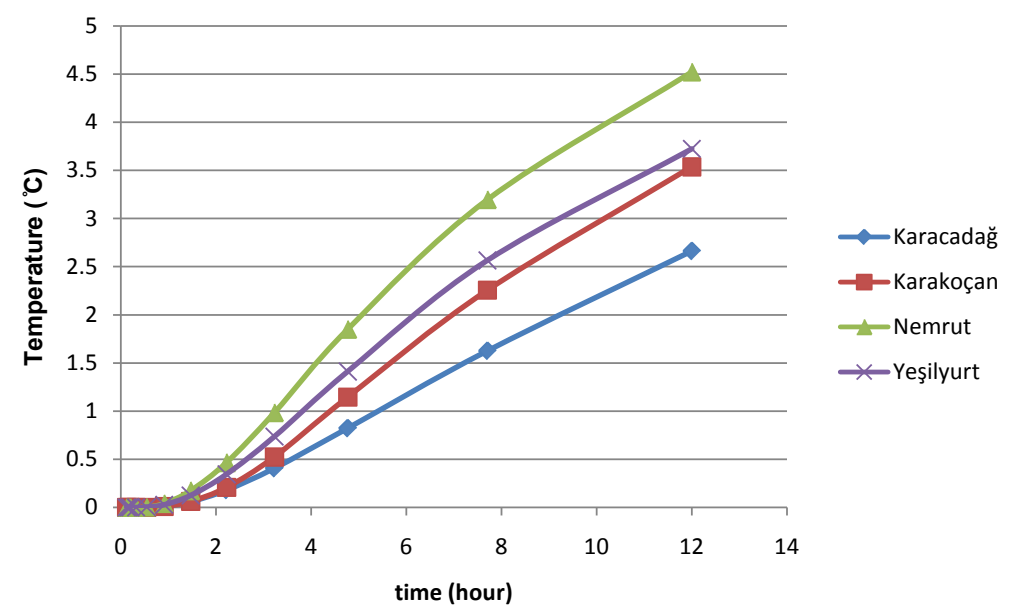

Figure 6. Temperature distribution versus time at the center of the wall.

time period. It is shown that Nemrut stone can reach to the highest temperature, whilst the Karacadag stone reaches up the lowest temperature.

\section{References}

[1] http://en.wikipedia.org/wiki/Building material

[2] Bayram, F. (2012) Predicting Mechanical Strength Loss of Natural Stones after Freeze-Thaw in Cold Regions. Cold Regions Science and Technology, 83-84, 98-102. http://dx.doi.org/10.1016/j.coldregions.2012.07.003

[3] Ozcelik, Y. (2011) Determination of the Regions Used as Facing and Building Stone According to the Material Characteristics in an Andesite Quarry. Engineering Geology, 118, 104-109. http://dx.doi.org/10.1016/j.enggeo.2011.01.005

[4] Celik, S.B., Cobanoglu, I. and Atatanir, L. (2013) General Material Properties of Denizli (SW Turkey) Travertine as a Building Stone. Bulletin of Engineering Geology and the Environment, 1, 1-14.

[5] Bicer, Y., Yildiz, C. and Pehlivan, D. (1996) Some Physical Properties of the Building Stones from Mardin, and Its Districts. Proceedings of the 1st Trabzon International Energy and Environment Symposium, Trabzon, 29-31 July 1996.

[6] Bicer, Y., Tanyildizi, V., Pehlivan, D. and Yildirim, S. (1993) A Research on the Physical Properties of the Natural Building Materials Available in Firat Basin. Journal of Faculty of Engineering and Architecture of Cukurova University, 8, 53-60.

[7] Bicer, Y., Tanyildizi, V. and Yildirim, S. (1994) A Research on the Physical Properties of the Natural Building Mate- 
rials Available in Cukurova. 3rd National Symposium on the Refrigeration and Acclimatization, Adana, 285-292.

[8] Korkanç, M. (2013) Deterioration of Different Stones Used in Historical Buildings within Nigde Province, Cappadocia. Construction and Building Materials, 48, 789-803. http://dx.doi.org/10.1016/j.conbuildmat.2013.07.033

[9] Zedef, V., Kocak, K., Doyen, A., Ozsen, H. and Kekec, B. (2007) Effect of Salt Crystallization on Stones of Historical Buildings and Monuments, Konya, Central Turkey. Building and Environment, 42, 1453-1457. http://dx.doi.org/10.1016/j.buildenv.2005.12.010

[10] Yavuz, A.B. (2012) Durability Assessment of the Alacati Tuff (Izmir) in Western Turkey. Environmental Earth Sciences, 67, 1909-1925. http://dx.doi.org/10.1016/j.buildenv.2005.12.010

[11] Ozisik, M.N. (1985) Heat Transfer-A Basic Approach. Mc Graw Hill. 